\title{
Comparative analysis of the functional behavior of costs for the construction of housing of the economy and comfort class
}

\author{
Olga Grushina ${ }^{1, *}$, Nina Poliakova ${ }^{1}$, and Natalia Shelomentseva ${ }^{1}$ \\ ${ }^{1}$ Baikal State University, 664003, Lenin str., 11, Irkutsk, Russia
}

\begin{abstract}
The article considers the issue of increasing the investment attractiveness for the developer of massive construction of economy class housing by possible coverage of costs and formation of satisfactory financial results. The application of mathematical apparatus of the derivation of linear function and margin analysis allowed us to determine that in practice the developer companies solve the problem of low profitability of the economy class housing at the expense of more expensive comfort class housing objects, manipulating with the distribution of fixed costs. As a result, the possibility of covering the general management costs of the developer from one meter of housing of any class is equalized. The solution to the problem is seen in the creation of a database of standard economy class housing projects with the mandatory allocation of variable and constant construction costs for each type of facility per square meter of the completed housing. Such data will allow construction companies to take full advantage of the opportunities of margin analysis, including determining the lower limit of the price of a square meter, breakeven output and the financial result of both a single object (margin revenue of an object) and the organization as a whole for the reporting period. However, the market approach only will not solve this issue: the state support through the financing of the governmental programs will provide affordable housing for citizens.
\end{abstract}

\section{Introduction}

The right of every citizen to housing enshrined in Article 7 of the Constitution of the Russian Federation cannot be provided by the "invisible hand" of the market. Mortgage was not a panacea: its rapid introduction in the mid-2000s led to an equally rapid rise in housing prices and the enslavement of hundreds of thousands of families in long-term debt slavery, which threatens with poverty and loss of a roof over one's head at any time at the next economic crisis, that is accompanied by higher rates and the fall in real incomes of citizens (carried out for the sake of the overpowering "good" goal of the inflation targeting). Understanding this has led to the creation of a number of governmental programs and subprograms aimed at solving the issue of providing

*Corresponding author: olga7771972@mail.ru 
affordable housing. The peculiarity of these programs is their target nature and the development of performance indicators that regulate the achievement of goals.

The trend to reduction of the key targets for the implementation of governmental programs also touched upon the program aimed at providing affordable housing for the Russian citizens. The reduction, in particular, affected those indicators that are contained in the Decree of the President of the Russian Federation of May 7, 2012 No. 600, namely: "Decrease in the cost of one square meter of housing by $20 \%$ by increasing the volume of commissioning of the economy class housing", and "Providing affordable and comfortable housing for $60 \%$ of the Russian families, who want to improve their living conditions". Such a situation challenges not brilliant results of the implementation of this governmental program.

It was shown in the Consolidated annual report on the implementation and evaluation of the effectiveness of the governmental programs of the Russian Federation [1] that within the framework of the state program "Provision of affordable and comfortable housing and communal services for citizens of the Russian Federation", the actual volume of housing construction in 2016 amounted to 79.8 million square meters, including 39.9 million square meters of the economy class housing. As a result, the actual value of the indicator decreased by $6.4 \%$ compared to 2015 (from 85.3 to 79.8 million square meters). The number of housing units put into operation in 2016 amounted to 1,156 thousand units, which is $3.4 \%$ less than in 2015. This is due to the crisis in the economy of the country, which caused a general decrease in the investment expenses of construction companies.

Implementation of the governmental program to provide affordable and comfortable housing directly depends on the capabilities and interest of developers to perform economy class housing. This interest is determined primarily by a clear interpretation of the parameters of such housing, as well as the possibility of optimizing costs at all stages of the construction. A preliminary analysis of the existing official and semi-official definitions of the economy class housing, and the dynamics of key indicators related to the possibility of increasing housing affordability, will show the current trends in this sector of the economy.

\section{Dynamics of the main indicators of housing affordability}

In Figures 1 and 2 we have summarized the rate of change in the indicators of price and housing commissioning, the volume of mortgage loans and the welfare of people over the past 12 years in the Russian Federation and the Irkutsk region. The data of the State Committee on Statistics of the Russian Federation have been used. During this period, our country experienced two crisis moments: the global crisis of 2008, which affected the economic situation in 2009, and the default of the ruble at the end of 2014, which had its consequences in 2015.

Figures 1 and 2 present a graphical demonstration of trends in housing construction, housing prices and mortgage loans during a period of rapid development of mortgage, crisis and post-crisis period in Russia and the Irkutsk region. The graphs show a noticeable correlation of the increase in mortgage volumes and the rate of growth in housing prices. Correlation with the introduction of housing is much less noticeable and manifests itself with some time lag.

The rate of increase in housing commissioning throughout the country has a stable growth trend of 4-6\%. Rapid development of the mortgage (from 2005 to 2007) led to a jump in the growth of housing commissioning by 16 and $21 \%$ in the pre-crisis period. However, the postcrisis period led to a drop in housing commissioning below the level of 2007. In 2011 and 2012 , the growth rate was restored to the level of 6.7 and $4.7 \%$ per year. The Irkutsk region shows much more contrasting trends: the growth rates of housing construction fluctuated at a higher level than in the Russian Federation: from 9 to 26\%, the introduction of mortgages led to an explosive growth in commissioning by $73 \%$ in the pre-crisis 2007 , reached the pre- 
crisis level, and the rate of growth remained at the level of 1-4\%. 2011 and 2012 show the growth rate of housing 3-4 times higher than in the country as a whole.

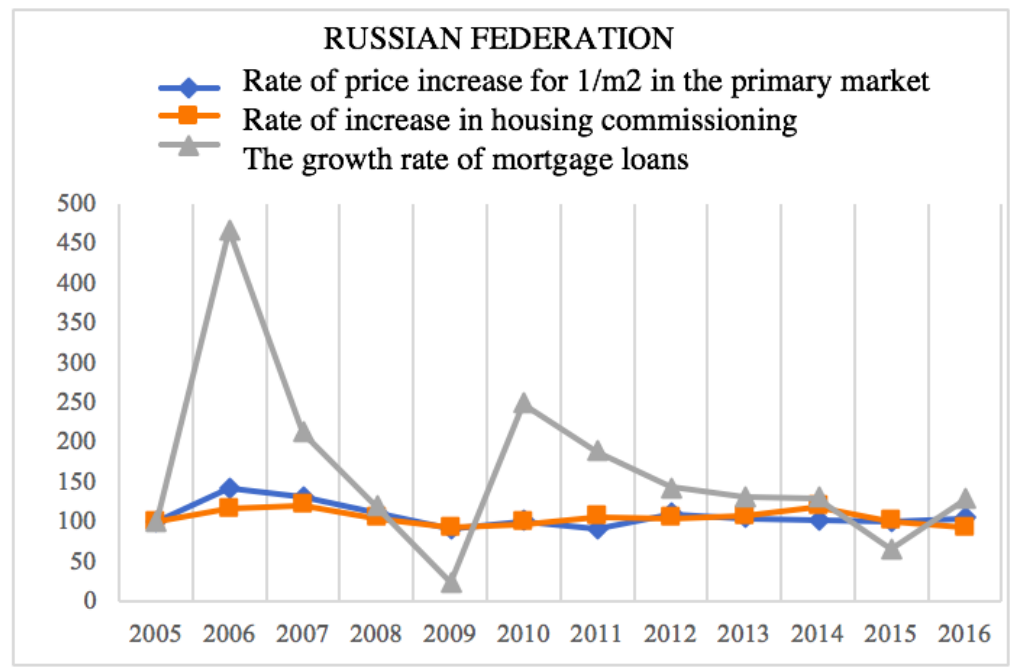

Fig. 1. The growth rate of housing commissioning, housing prices and the volume of mortgage loans issued in the Russian Federation (calculated and built by the authors based on the state statistics).

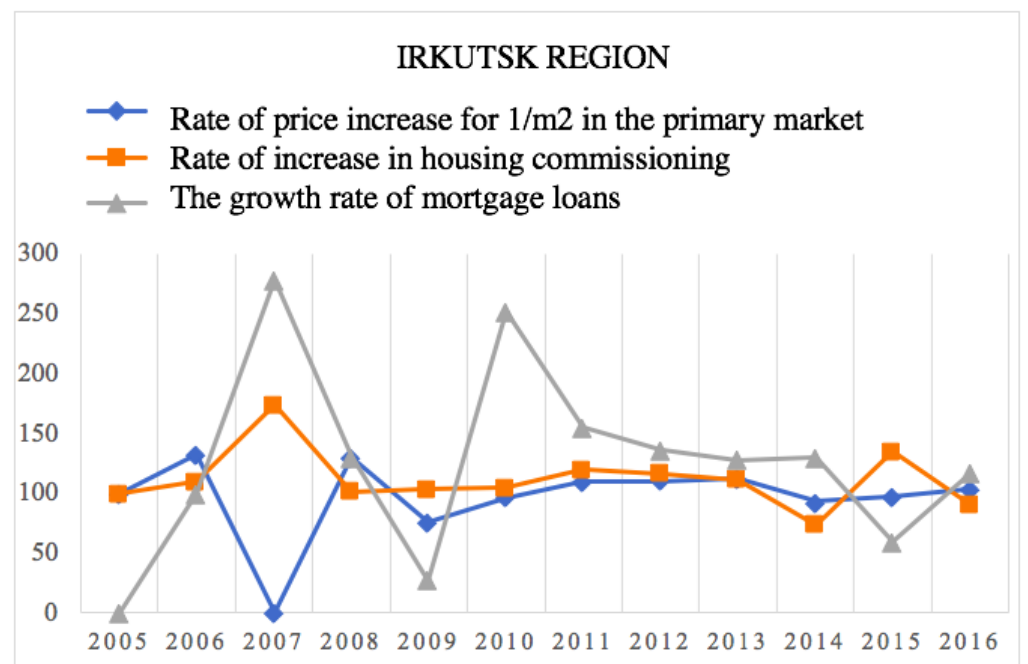

Fig. 2. The growth rate of housing commissioning, housing prices and the volume of mortgage loans issued in the Irkutsk region (calculated and built by the authors based on the state statistics.

In 2013-2014, in Russia, there was an increase in housing commissioning. A maximum after the mortgage boom of 2005-2006 was observed in $2014(+19.4 \%)$; the fall of the ruble and the sharp rise of the interest rates on loans led to a reduction in commissioning in 2016 by $6.5 \%$. For regions, in particular for the Irkutsk region, the consequences were more radical: already in 2014 housing commissioning fell by $27 \%$, the reasons were not only in the low purchasing power of the population and the jump in lending rates in November (about $50 \%$ of housing in the Irkutsk region is commissioned by the end of the fourth quarter), but also ones of local importance - the lack of land, poor pre-design preparation, underdeveloped infrastructure and problems in the commissioning of the housing [2, pp. 12-13]. In 2015, 
unfinished facilities were commissioned, but macroeconomic problems remained, and 2016 showed a decline of $8.5 \%$, coinciding with the all-Russian trend.

The number of apartments built does not decrease, but their area significantly diminished. "One-room apartments ranging from 22 to 25 square meters worth up to 1 million rubles, $750-850$ thousand rubles, located in remote areas of the city are in demand. This is so-called "first" housing, which is acquired by young families, students, people moving from small towns and not having the means to purchase an apartment of a larger area in the center of the city "[3, p. 942]. "Having a small but own apartment gives a certain freedom to a young family, but for a long time it will be forced to exist in a small area with all the ensuing consequences - crowding, lack of space for children and adults, the inability to use modern household appliances because of the limited size of the apartment, lack of privacy, etc. The results are the growth of discontent with living conditions, divorces, and the formation of feelings of injustice" [3, p. 942]. Construction companies that were able to refocus on the primary construction of small one-room apartments and follow the changed opportunities of the Russians citizens managed to benefit, despite the fact that the segment of the economy class housing is low-profitable for builders, as profit is formed in the segment of comfort class. "This situation is typical not only for some regions, but also for Russia as a whole. ... There is a danger that in 15-20 years we will face a situation when the secondary housing market will be full of small-sized and morally obsolete housing "[4, p. 49].

The trend of changes in the volume of the issued mortgage loans most vividly correlates with the crisis events in the economy: in Russia as a whole, and in the Irkutsk region, the volume of mortgage loans fell in 2009 by about three quarters, and in 2015 - by a third from previous periods. "So, the volume of loans issued by the end of 2013 more than doubled compared to the beginning of 2008, namely in 2.06 . At the same time, based on the analysis, we can say that demand began to grow only since the beginning of 2011, which is connected with the financial crisis of 2008" [5, p. 30].

"The mortgage market in the first half of 2016 grew by $44 \%$, but did not reach the volume of 2014. High growth rates are explained by the effect of a low base (in the first half of 2015, the volume of mortgage loans fell by $40 \%$ as compared to the first half of the year 2014), and support from the subsidy program (40\% of the total volume of mortgage loans - 145 thousand loans worth 262 billion rubles" [6, p. 948].

The statistics cited confirm that housing construction, as the main factor in the growth of housing provision in the country and in the regions, is currently in bad times, and therefore, needs to be stimulated by both investors and the federal and regional government. The problem of housing provision, in our opinion, cannot be solved without active state intervention.

A perfect market (perfect competition) cannot provide all citizens with housing by their methodological nature, and such a market does not exist. The modern market contains a number of imperfections, which studies modern economic science and which inevitably, since the time of J. Keynes, comes to the conclusion that it is necessary to overcome imperfections of the market with the help of the state [7].

\section{Calculation of the function of the cost behavior for building a square meter of housing}

Territorial development of the city due to the construction of micro-districts of the economy class on its outskirts is a widespread process in Russia in general, and in Irkutsk in particular. Affordable housing in these new buildings provides the possibility of implementing resettlement programs from dilapidated and emergency housing, the consequences of natural disasters, relocation from areas equivalent to the Far North. Due to what factors the decline in prices for housing of this class is provided? 
First of all, we have to determine what kind of housing is considered to be an economy class one: contracts for the acquisition of which per $1 \mathrm{sq}$. m. of the total area of such residential premises does not exceed the minimum of 35 thousand rubles or $80 \%$ of the market value of $1 \mathrm{sq}$. m. of total area. In accordance with the order of the Ministry of Regional Development "On approval of methodological guidelines for determining the characteristics of the economy class housing" the size of an individual house should not exceed $150 \mathrm{~m} 2$, and the area of apartments is limited to $126 \mathrm{~m} 2$. One-room apartment can be recognized as the economy class housing, if its size is limited to 28-45 m2, two-room apartment - 44-60 $\mathrm{m} 2$. The minimum area of the room $(14 \mathrm{~m} 2)$ and the kitchen $(5 \mathrm{~m} 2)$ has been established $[8,250]$. Many studies have been devoted to this type of housing, both in legal and technological aspects $[9,10,11]$.

We believe that we should pay attention to the structure and function of the cost behavior for such objects. To do this, let us consider a structural analysis of the cost of the companydeveloper on the example of the two objects - "Nizhniaia Lisikha" and "Lugovoie". "Nizhniaia Lisikha" is a multi-apartment nineteen-store residential building with built-in nonresidential premises and an underground parking lot, located in Oktyabrsky district of Irkutsk on Baikalskaia Street, belongs to the category of comfortable housing. The technology of the structure - it is monolithic reinforced concrete. The time frame for the construction of the project "Nizhniaia Lisikha" was from February 2016 to November 2017, the planned cost of the construction was 1,128,000 thousand rubles.

The project "Lugovoie" belongs to the category of economy class housing, it provides for the construction of 9 six-store multi-apartment residential buildings in the working village of Markovo of the Markovsky municipality of the Irkutsk region with construction dates from March 2015 to December 2016. Technologically it is masonry autoclaved aerated concrete blocks. The planned construction cost is 573,000 thousand rubles.

Structural analysis has shown that the largest share in the total amount of costs is taken by direct costs for (costs for production) - $81.26 \%$, where $52.99 \%$ - for materials, $27.44 \%$ costs for subcontracting and production services, $13.92 \%$ - transportation services, $5.65 \%$ wages of workers. Preparatory expenses were $7.24 \%$, where $90.50 \%$ - expenses for the project, $7.79 \%$ - expenses for registration of land for construction, $1.70 \%$ - design costs. Preparatory costs are very specific for the construction, and they are at the level of almost $1 / 10$ of the total costs.

Let us construct the equation of the cost behavior using the method of the higher and lower points. The coefficients of the cost equation $y=a+b \cdot x$ are defined as follow:

$$
\begin{gathered}
b=\frac{y^{\max }-y^{\min }}{x^{\max }-x^{\min }}, \\
a=y^{\max }-b \cdot x^{\max }, \\
a=y^{\min }-b x^{\min },
\end{gathered}
$$

where $a$ - constant costs for the period; $b$ - specific variable costs per unit of volume. The method of the highest and lowest point allows us to divide costs into constants and variables from the data of the dynamic series. We had quarterly data on the total costs and volumes of construction work for the objects under consideration (Tables 1-2).

Table 1. The scope of construction works and costs for the object "Nizhniaia Lisikha". 


\begin{tabular}{|l|c|c|c|c|c|}
\hline \multicolumn{1}{|c|}{ "Nizhniaia Lisikha" } & 1 quarter & 2 quarter & 3 quarter & 4 quarter & $\begin{array}{c}\text { Total, } \\
2016\end{array}$ \\
\hline $\begin{array}{l}\text { The scope of work } \\
(\mathrm{m} 2), 2016\end{array}$ & 391.89 & 877.60 & 1838.00 & 1010.07 & 4117.56 \\
\hline $\begin{array}{l}\text { Revenue }(62 \\
\text { thousand rubles per 1 } \\
\text { m2) }\end{array}$ & 24297.18 & 54411.2 & 113956 & 62624.34 & 255288.72 \\
\hline $\begin{array}{l}\text { Total costs, thousand } \\
\text { rubles }\end{array}$ & 25413.51 & 28865.55 & 87878.22 & 15660.06 & 157817.3 \\
\hline
\end{tabular}

As a result, the cost function for the "Nizhniaia Lisikha" object looks like this:

$$
y=8485,82+43,195 \cdot x
$$

where: $y$ - total cost; $x$ - the volume of completed construction work in $\mathrm{m} 2$, or

$$
y=8485,82+0,6967 \cdot x,
$$

$y$ - total cost; $x$ - revenue, thousand rubles.

If we consider the obtained equations (4) and (5) in terms of the variables $(x, y)$, then the point of intersection of the lines with the ordinate axis for zero volume shows the magnitude of fixed expenses for the quarter (8485.82 thousand rubles), and the coefficients 43.195 thousand rubles and 0.6967 thousand rubles show the value of variable costs per $1 \mathrm{~m} 2$ and per 1 thousand rubles of revenue.

Similarly, we will calculate the cost equation for "Lugovoie", using the data in Table 2.

Table 2. The scope of construction works and costs for the object "Lugovoie".

\begin{tabular}{|c|c|c|c|c|c|}
\hline "Lugovoie" & 1 quarter & 2 quarter & 3 quarter & 4 quarter & Total, 2016 \\
\hline $\begin{array}{c}\text { The scope of work } \\
(\mathrm{m} 2), 2016\end{array}$ & 1748,07 & 2839,09 & 3853,05 & 3532,64 & 11972,86 \\
\hline $\begin{array}{c}\text { Revenue }(62 \\
\text { thousand rubles per 1 } \\
\text { m2) }\end{array}$ & 67475,5 & 109588,87 & 148727,73 & 136359,9 & 462152,40 \\
\hline $\begin{array}{c}\text { Total costs, } \\
\text { thousand rubles }\end{array}$ & 19726,02 & 31959,33 & 54817,06 & 18607,74 & 136600,8 \\
\hline
\end{tabular}

As a result, the cost function for the "Lugovoie" object looks like this:

$$
y=-9415,16+16,67 \cdot x
$$

where: $y$ - total cost; $x$ - the volume of completed construction work in $\mathrm{m} 2$, or

$$
y=-9415,16+0,4319 \cdot x,
$$

$y$ - total cost; $x$ - revenue, thousand rubles.

If we consider equations (6), (7) in terms of the variables (x,y), then the point of intersection of the lines with the ordinate axis for zero volume shows the magnitude of fixed costs for the quarter (-9415.16 thousand rubles), and the coefficients $b=16.67$ thousand rubles and $b=0.4319$ thousand rubles show the value of variable costs per $1 \mathrm{~m} 2$ and per thousand rubles of revenue. 
In the cost equation, negative fixed costs are explained by the fact that there is a hidden process of covering the fixed costs of "Lugovoie" at the expense of the more expensive "Nizhniaia Lisikha". In practice, this is quite realistic, because how to build a housing of the economy class? To return constant costs from other construction sites.

"Initially, the segment of the economy class housing is low-profitable for builders; profit is formed in the segment of business class. But statistics show that the economy class housing is the most in demand on the housing market" [13, p. 97]. We believe that the low profitability of the economy class housing is compensated by its volumes; construction organizations can win, first, on the effect of scale, and secondly, to cover their constant costs by selling more expensive facilities, which our calculations confirmed.

The simplicity and accessibility of the method of higher and lower points is the reason for its wide application. However, a significant disadvantage of this method is the fact that its reliability entirely depends on the choice of points; in this case, it is necessary to exclude random, uncharacteristic points from the calculation. Applying this method of allocating costs to the variable and constant parts, one can get fairly early enough preliminary data, primarily for conducting a margin analysis, which, if necessary, can be cross-checked and refined.

Marginal analysis of the cost of housing of various classes for the same developer is the most obvious method of opening reserves of investors' interests in the implementation of governmental programs to ensure the availability of housing for the population of the Russian Federation.

We conducted a marginal analysis of revenues and costs per square meter of housing construction of the economy and comfort class facilities, sharing costs directly by their economic nature.

To conduct a margin analysis, one must modify the initial cost classification of the company, referring costs to those that have a variable or permanent nature.

1. Variable costs:

Direct costs:

- materials;

- transport services;

- subcontracting and production services;

- workers' wages and taxes;

Variable manufacturing production overhead (MPO):

- $\quad$ wages of workers (contributions to extra-budgetary funds);

- maintenance of workers (overalls, means of protection, food).

2. Fixed costs:

Fixed manufacturing production overhead:

- electricity;

- other communal services;

- $\quad$ safeguarding land, buildings, premises;

- $\quad$ repair, maintenance and operation of machinery and equipment;

- $\quad$ salary of maintenance staff;

- $\quad$ salaries of maintenance staff (contributions to extra-budgetary funds);

- maintenance of staff;

- $\quad$ property tax and transport tax;

Preparatory costs;

General management costs;

Commercial costs.

In the calculations, we deliberately do not include general management and commercial costs of the organization as a whole, since they are covered by the object profit margin (the 
difference between the profit margins of the object and the fixed costs that are linked to the object) [14].

The results of the calculation are presented in Table 3.

Table 3. The incomes and expenses of the developer per $1 \mathrm{~m}^{2}$ of housing, rubles.

\begin{tabular}{|l|c|c|c|c|c|}
\hline \multicolumn{1}{|c|}{ Object } & $\begin{array}{c}\text { Average } \\
\text { price }\end{array}$ & $\begin{array}{c}\text { Variable } \\
\text { costs }\end{array}$ & $\begin{array}{c}\text { Marginal } \\
\text { revenue }\end{array}$ & $\begin{array}{c}\text { Fixed costs } \\
\text { of the } \\
\text { objects }\end{array}$ & $\begin{array}{c}\text { Marginal revenue } \\
\text { on the object }\end{array}$ \\
\hline $\begin{array}{l}\text { "Nizhniaia } \\
\text { Lisikha" }\end{array}$ & 62000 & 31278 & 30722 & 4060 & 26662 \\
\hline $\begin{array}{l}\text { "Lugovoie } \\
\text { " }\end{array}$ & 38600 & 10510 & 28090 & 581 & 27509 \\
\hline
\end{tabular}

As a result of direct counting, variable costs per $1 \mathrm{~m} 2$ for both objects turned out to be less than those deduced mathematically (the conditionally constant nature of costs is perceived by the mathematical apparatus as variable), but the assumption has been confirmed that fixed costs are attributed to more expensive objects: fixed costs of $1 \mathrm{~m} 2$ of "Nizhniaia Lisikha" happened to be seven times higher than the same expenses of "Lugovoie"! In this way, the construction company receives approximately equal amount of marginal revenue per square meter of an object of any class.

\section{Conclusion}

The problem of ensuring the availability of housing cannot be solved without a clear vision of the parameters of economy class housing, technology of its construction and economic justification of costs, which can make attractive investments in the construction of housing of this class.

We agree with the authors who outline the following factors for reducing the cost of housing construction: public funding at the design level and creation of the municipal infrastructure base [15, p. 23]; the use of standard (re-applied) projects to reduce the cost of construction at the design stage $[4$, P. 56]; the use of cheap building technologies, widely used in the global practice [10, p. 170].

We believe that a clear definition of parameters of such housing and the creation of a database of standard projects, including, inter alia, the values of basic variables and fixed costs per $1 \mathrm{~m} 2$ of the facility will allow potential developers, for a short number of iterations, to determine the breakeven volume of housing construction, the amount of coverage of their management expenses, and possible profit from the sale of potential objects.

\section{References}

1. Government of Russia, Consolidated annual report on the implementation and evaluation of the effectiveness of state programs of the Russian Federation in 2016 (http://static.government.ru/media/files/i0d1XvJka1R0C7eEgp2p5nHHhbnHyVH8.pd f, 2016)

2. L. A. Kaverzina, T. I. Kubasova, O. K. Belsky, A. V. Dobrya, Problems of Social and Economic Development of Siberia, 2(28), 9-15 (2017)

3. T. V. Svetnik, Bulletin of the Irkutsk State Economic Academy, 25(6), 941-946 (2015)

4. Yu. V. Medianik, Housing Strategies, 1(1), 45-60 (2014)

5. O. I. Korotkova, Law and Order in the Modern Society, 20, 25-36 (2014) 
6. T. I. Kubasova, L. A. Kaverzin, Bulletin of the Baikal State University, 26(6), 947-954 (2016)

7. O. Grushina, G. Khomkalov, JAES, 3(41), 501-512 (2016)

8. A. D. Kornilov, Traditions and innovations in construction and architecture: materials of the 70th jubilee All-Russian scientific and technical conference (2013)

9. E. A. Ryazanova, N. G. Rygalina, Bulletin of Tver State University, Series in Law, 2, 141-153 (2016)

10. M. A. Pechenskaya, Economic aspects of management of the construction complex in modern conditions: collected papers, 169-175 (2015)

11. I. V. Moiseenko, E. V. Noskova, Russian Entrepreneurship, 19 (241), 24-31 (2013).

12. A. O. Gelfand, Notes of the Scientist, 2, 24-26 (2015)

13. Yu. E. Ostrjakova, Genesis of economic and social problems of subjects of a market economy in Russia, T. 1, 9, 95-98 (2015)

14. O. V. Grushina, I. G. Khomkalova, State Administration: an electronic bulletin of the Moscow State University, 28 (2011)

15. I. A. Zaitseva, V. V Shutenko, Yu. E. Ostryakova, Modern Science-Intensive Rechnologies: Regional Annex, 1, 23-31 (2012) 